\title{
FAKTOR-FAKTOR YANG MEMPENGARUHI KINERJA GURU SMK BIDANG PRODUKTIF PASCA SERTIFIKASI
}

\author{
Sutopo \\ Jurusan Pendidikan Teknik Mesin, Fakultas Teknik Universitas Negeri Yogyakarta \\ sutopo@uny.ac.id
}

\begin{abstract}
This study aimed to quantitatively describe the variables of certification's impact, teachers' work ability, work motivation, work commitment, and teacher performance on Vocational High School (SMK) teachers after the teacher certification program is implemented. This study uses quantitative methods to obtain measurable data that is descriptive, comparative and associative and to answer the problem formulation and research questions. The descriptive analysis of a portion of the research data resulted in research findings which show: (1) The impact of SMK teachers certification, which were developed from the pride, professionalism, and welfare aspects; obtain information that $34 \%$ are categorized as very good, $58 \%$ are in good category, $6 \%$ are in moderate category and $2 \%$ are in poor category, (2) the teachers' work ability which were developed from the aspects of pedagogical competence, professionalism, personality and social, obtain information that $32 \%$ are categorized as very good, $60 \%$ are good, $6 \%$ are moderate and $2 \%$ are in poor category, (3) teachers' work motivation which were indicated from the aspects of needs of achievement, existence and power, affiliation, selfactualization and independence, and growth expectations, obtained information that $24 \%$ are categorized as very good, $60 \%$ are in good category, and $16 \%$ are in moderate category, (4) work commitment of teachers which were developed from the aspects of affective commitment, continuity and normative, obtained findings that $26 \%$ are in very good category, $64 \%$ are good, and $10 \%$ are in moderate category, (5) the performance of SMK teachers which were developed from the aspects of fullfilment of the main duties, implementation of duties other than the main duties, and professional development, obtained information that $20 \%$ are categorized as very good, $64 \%$ are in good category, and $16 \%$ are in moderate category.
\end{abstract}

Keywords: impacts, teacher certification, smk, teacher performances, quantitative

\begin{abstract}
ABSTRAK
Penelitian ini bertujuan mendeskripsikan secara kuantitatif variabel dampak sertifikasi, kemampuan kerja guru, motivasi kerja guru, komitmen kerja guru, dan kinerja guru SMK setelah mengikuti program sertifikasi guru. Penelitian ini menggunakan metode kuantitatif untuk memperoleh data terukur yang bersifat deskriptif, komparatif dan asosiatif. Hasil analisis secara deskriptif sebagian data hasil penelitian menunjukkan bahwa: (1) Dampak sertifikasi guru SMK yang dikembangkan dari aspek kebanggaan, keprofesionalan dan kesejahteraan diperoleh informasi sebesar 34\% termasuk kategori amat baik, 58\% termasuk kategori baik, (2) kemampuan kerja guru yang dikembangkan dari aspek kompetensi pedagogis, professional, kepribadian dan sosial diperoleh informasi sebesar 32\% termasuk kategori amat baik, 60\% kategori baik, (3) motivasi kerja guru yang diindikasikan dari aspek kebutuhan berprestasi, eksistensi dan berkuasa, berafiliasi, aktualisasi dan kemandirian, dan harapan pertumbuhan diperoleh informasi sebesar $24 \%$ termasuk kategori amat baik, $60 \%$ termasuk kategori baik, (4) komitmen kerja guru yang dikembangkan dari aspek komitmen afektif, kontinuitas dan normatif diperoleh temuan sebesar 26\% termasuk aktegori amat baik, 64\% termasuk kategori baik, (5) kinerja guru SMK yang dikembangkan dari aspek pelaksanaan tugas pokok, pelaksanaan tugas di luar tugas pokok dan pengembangan keprofesionalan diperoleh informasi sebesar 20\% termasuk kategori amat baik, $64 \%$ termasuk kategori baik.
\end{abstract}

Kata kunci: dampak sertifikasi, kinerja guru SMK, kuantitatif

\section{PENDAHULUAN}

Faktor kunci penentu daya saing bangsa dalam era global adalah ilmu pengetahuan dan teknologi serta sumber daya manusia (Trilling \& Hood, 1999: 5-6; Wen, 2003: 21-94). Analisis tersebut didukung oleh penelitian Bank Dunia (Samani, 2008:3) yang menunjukkan 
bahwa kekuatan suatu negara dalam era global ditentukan oleh faktor-faktor: (1) inovasi dan kreatifitas (45\%), jaringan kerjasama / networking (25\%), teknologi / technology (20\%), dan sumberdaya alam/natural resources (10\%). Hal ini menunjukkan adanya indikasi bahwa suatu bangsa yang memiliki keunggulan komparatif dalam sumber daya alam, tidak akan mampu banyak berbuat dalam kancah persaingan global tanpa didukung oleh keunggulan sumber daya manusia (SDM).

Berdasarkan data dari berbagai survey internasional, kualitas hasil pendidikan Indonesia masih relatif rendah dan tertinggal oleh negara-negara lain, termasuk sesama negara ASEAN. Laporan UNDP (United Nation Development Project) tahun 2007/2008, tentang Index Pembangunan Manusia (IPM) atau HDI (Human Development Index) Indonesia berada di peringkat 107 dari 177 negara. Apabila disandingkan dengan negara sekitar, tingkat HDI Indonesia jauh tertinggal. Contoh, Malaysia berada diperingkat 63, Thailand 78 dan Singapura 25. Indonesia hanya lebih baik dari Papua Nugini dan Timor Leste yang berada pada posisi 145 dan 150. Hal ini menunjukkan bahwa kualitas pendidikan kita masih jauh tertinggal dengan negara-negara tetangga, sehingga perlu pembenahan secara cepat dan tepat, agar negara kita dapat sejajar dengan negara maju lainnya. (http://hdrstats.undp.org/countries/country_fact _sheets/cty_fs_IDN.html).

Melalui pengalaman pendidikan masa lalu yang telah membentuk masyarakat dan budaya Indonesia terjerumus dalam berbagai krisis, diperlukan reformasi pendidikan yang lebih berorientasi pada peningkatan mutu pendidikan dalam semua jenjang dan jenis pendidikan. Peningkatan kualitas pendidikan merupakan syarat mutlak untuk mempercepat terwujudnya masyarakat yang madani dan berdemokratis. Masyarakat madani yang demokratis hanya dapat dibentuk melalui perwujudan masyarakat yang cerdas. Masyarakat yang cerdas hanya dapat dibentuk melalui pendidikan yang berkualitas (Tilaar, 2000:1-25).

Pendidikan kejuruan (SMK) sebagai lembaga pendidikan yang bertujuan menyiapkan lulusannya memasuki dunia kerja memiliki peran strategis dalam menyiapkan SDM khususnya tenaga kerja tingkat menengah. Sebagai sub sistem pendidikan nasional, pendidikan kejuruan harus berbenah guna mengantisipasi kebutuhan dan tantangan masa depan. Hal ini perlu dilakukan terus menerus diselaraskan dengan kebutuhan perkembangan dunia usaha dan dunia industri, serta ilmu pengetahuan dan teknologi. Perbaikan pendidikan menengah kejuruan diharapkan dapat menciptakan tenaga kerja terampil yang memenuhi kebutuhan dunia usaha dan industri, serta mencetak manusia yang mampu menciptakan lapangan kerja sendiri (Depdiknas, 2008:1-66).

Meskipun menunjukkan peran positif, beberapa studi masih menemukan permasalahan yang dihadapi oleh pendidikan kejuruan. Permasalahan tersebut terkait dengan kontribusi bagi masyarakat, kualitas penyelenggaraan program, pembelajaran, kesempatan lulusan mendapatkan pekerjaan, dan tantangan perubahan yang begitu cepat. Governing Board Members of TVET (2004), mencatat beberapa isu dan trend pendidikan kejuruan di kawasan Asia Tenggara yang antara lain menunjukkan:

(1) limited number of qualified personnel with high quality including commitment and result-focused, (2) limited capacity in utilization of research and evaluation as tools for development, (3) unsystematic or lack of staff development programs, (4) negative image of VTE especially among community members, (5) inadequate number of qualified teachers, (6) lack of public-private sector partnership in training teachers and students, (7) curriculum irrelevancy and the misfit of VTET graduates, (8) copying with IT explosion and rapid expansion of ICT, (9) lacking in the development of teaching and learning resources, dan 
(10) lack of facilities, especially lab and workshops.

Pada lingkup nasional, permasalahan pendidikan kejuruan terutama menyangkut relevansi dan kolaborasi antara sekolah dengan dunia usaha/indusri. Data Biro Pusat Statistik menunjukkan bahwa tingkat pengangguran lulusan SMK meningkat sedangkan lowongan kerja yang belum terisi lulusan SMK juga meningkat (Kompas, 5 Januari 2009). Hal ini menunjukkan relevansi pendidikan di SMK dengan kebutuhan tenaga kerja yang masih rendah. Sementara itu hasil observasi empirik di lapangan masih mengindikasikan bahwa sebagian besar lulusan SMK kurang mampu menyesuaikan diri dengan perubahan ilmu pengetahuan dan teknologi, sulit untuk bisa dilatih kembali, dan kurang bisa mengembangkan diri.

Direktorat Pembinaan SMK juga memprediksi tantangan yang akan dihadapi para lulusan SMK akan semakin meningkat, untuk itu peserta didik perlu: (1) memiliki keterampilan dasar yang memungkinkan pengembangan dan penyesuaian diri mengikuti perkembangan iptek; (2) mengumpulkan, menganalisa, dan mengorganisasi informasi; (3) mengkomunikasikan ide dan informasi; (4) merencanakan dan mengorganisasikan kegiatan; (5) mampu bekerjasama dan kerja berkelompok; (6) mampu memecahkan masalah; (7) berfikir logis dan mampu menggunakan ide-ide matematik; (8) menguasai bahasa komunikasi global (bahasa Inggris). Upaya membekali lulusan SMK dengan berbagai kompetensi tersebut selaras dengan analisis Bank Dunia (Joy Nam, 2009:3) yang merumuskan perubahan kebutuhan pasar kerja:

...it is necessary to examine the changing economic context for education and skills demands in the labor market and the trends that reflect these new demands. The dynamic forces of the knowledge economy, accompanied by changing markets, scientific and technological advances, and increasing globalization and internationalization, call for a new face of skills and competencies. Such skills and competencies are not only highly desired, but also often required in order to meet the demands of this changing economic context and labor market realities.

Faktor mendasar yang dapat meningkatkan kinerja SMK menjadi lebih optimal adalah faktor kinerja guru-gurunya. Guru merupakan komponen yang paling menentukan dalam sistem pendidikan secara keseluruhan yang harus mendapat perhatian yang pertama dan utama. Argumentasi tersebut didukung oleh Fullan (2001:115), yang menyatakan bahwa "educational change depend on what teacher do and think". Menurut Surya (2008:40), tumpuan kualitas pendidikan pada sosok guru merupakan hal yang wajar, karena guru sebagai pendidik merupakan jabatan yang amat strategis dalam menunjang proses dan hasil kinerja pendidikan secara keseluruhan.

Salah satu cara yang dilakukan oleh pemerintah untuk mengatasi permasalahan rendahnya kualitas guru ini adalah dengan mengadakan sertifikasi. Keputusan pemerintah mengadakan sertifikasi bagi tenaga pendidik (guru) bertujuan untuk; (1) menentukan kelayakan guru dalam melaksanakan tugas sebagai pendidik profesional, (2) meningkatkan proses dan dan mutu hasil pendidikan, (3) meningkatkan martabat guru, dan (4) meningkatkan profesionalitas guru (Depdiknas, 2008a:5).

Tantangan nyata yang harus dihadapi guru SMK pasca sertifikasi adalah bagaimana guru SMK dapat survive dan mampu memberikan learning services yang sejalan dengan tuntutan dinamika perkembangan ilmu dan teknologi di abad 21. Guru SMK harus tanggap dan selalu belajar terhadap perubahan dunia dan keinginan masyarakat, termasuk dunia usaha dan dunia industri. Arends (2004:20-28) menjelaskan bahwa menjadi seorang guru yang efektif, guru harus; (1) memiliki kualitas personal yang memungkinkan 
untuk mengembangkan hubungan antar manusia (siswa, orangtua, dan kolega); (2) dapat menciptakan ruang kelas yang demokratis sebagai model keadilan sosial untuk peserta didik; (3) memiliki dasar pengetahuan yang luas yang berhubungan dengan materi pelajaran, pembangunan manusia dalam proses pembelajaran, dan pedagogi; (4) memiliki pengalaman pengajaran yang efektif untuk merangsang motivasi siswa, meningkatkan prestasi belajar dan mengembangkan pola berpikir tinggi, dan menghasilkan siswa yang mandiri;

Berbagai permasalahan dan tantangan guru di atas makin menunjukkan pentingnya upaya untuk meningkatkan kinerja guru. Guru yang memiliki kinerja rendah tidak saja gagal memenuhi standar kinerja, namun juga akan memberikan pengaruh buruk kepada orang lain (Jones, Jenkin \& Lord, 2006:2). Guru yang memiliki kinerja rendah dapat berdampak negatif dalam hal: (1) reputasi dan citra sekolah di masyarakat; (2) pencapaian kinerja sekolah; (3) kinerja guru lain; (4) kinerja staf pendukung; dan (5) kepemimpinan dan manajerial sekolah.

Sejak kebijakan program sertifikasi guru digulirkan oleh pemerintah (2007), sampai saat ini belum ada penelitian yang secara komprehensif mengungkap kinerja guru SMK pasca sertifikasi dan bagaimanakah dampak sertifikasi guru terhadap kinerjanya. Secara detail, penelitian ini berusaha mengungkap dampak sertifikasi guru terhadap faktor-faktor psikologis yang secara teori mempengaruhi kinerja guru. Faktor-faktor psikologis tersebut adalah kemampuan kerja, motivasi kerja, dan komitmen kerja guru. Penelitian ini diharapkan mampu memberikan informasi kepada pembuat kebijakan tentang kinerja guru SMK setelah memperoleh sertifikat pendidik berdasarkan data-data yang digali secara kuantitatif dan diperdalam dengan data kualitatif, sehingga pelaksanaan program sertifikasi guru, khususnya guru SMK dapat disempurnakan prosesnya. Hasil penelitian diharapkan dapat menjadi bahan masukan bagi perumus kebijakan dalam pembinaan tenaga pendidik terutama guru SMK di waktu mendatang. Permasalahan dalam penelitian ini dibatasi dengan rumusan masalah bagaimana gambaran perubahan kemampuan kerja guru, motivasi kerja guru, komitmen kerja guru dan kinerja guru SMK pasca sertifikasi.

\section{METODE}

Penelitian evaluasi dampak sertifikasi guru SMK terhadap kinerja sekolah ini termasuk jenis penelitian evaluasi dengan menggunakan metode kuantitatif-kualitatif (mixed methods). Secara utuh, desain penelitian yang digunakan adalah desain sequential explanatory atau penelitian kombinasi model. Penelitian kombinasi dengan desain sequential explanatory adalah penelitian yang menggabungkan metode penelitian kuantitatif dan kualitatif secara berurutan, di mana pada tahap pertama penelitian dilakukan dengan menggunakan metode kuantitatif dan pada tahap kedua dilakukan dengan metode kualitatif (Cresswel, 2009:209). Metode kuantitatif berperan untuk memperoleh data kuantitatif yang terukur, yang dapat bersifat deskriptif, komparatif dan asosiatif sedangkan metode kualitatif berperan untuk membuktikan, memperdalam, dan memperluas data kuantitatif yang telah diperoleh pada tahap awal.

Berdasarkan ilustrasi pada Gambar 1 dapat dijelaskan bahwa penelitian ini dilaksanakan menggunakan metode penelitian campuran (mixed methods) dengan pendekatan sequential explanatory design. Pada tahap awal, penelitian dilakukan dengan menggunakan metode kuantitatif. Kerangka konseptual pada Gambar 1 menunjukkan bahwa kinerja guru sebagai variabel terikat dipengaruhi oleh variabel-variabel kemampuan guru, motivasi guru, komitmen kerja guru, dan dampak sertifikasi guru.

Pada tahap akhir, peneliti akan menggunakan metode kualitatif (dalam Gambar 1 disimbolkan oleh kotak dengan bintik-bintik hitam). Data kualitatif yang diperoleh pada 
tahap akhir akan digunakan untuk membuktikan, memperluas dan memperdalam data kuantitatif sehingga diperoleh hasil penelitian yang lebih lengkap.

Dilihat dari bentuk evaluasi maka penelitian ini termasuk evaluasi dampak (impact evaluation). Pemilihan evaluasi dampak didasarkan pada pemikiran antara lain:
(1) program sertifikasi guru telah menghabiskan dana yang sangat besar, sehingga seluruh stakeholder sekolah perlu

tahu "effect" perbedaan yang terjadi; (2) program sertifikasi guru yang telah dilaksanakan sejak tahun 2007 telah cukup matang (setlled stage) untuk dievaluasi dampaknya; (3) evaluasi lebih fokus pada outcome sehingga informasi dapat digali lebih mendalam.

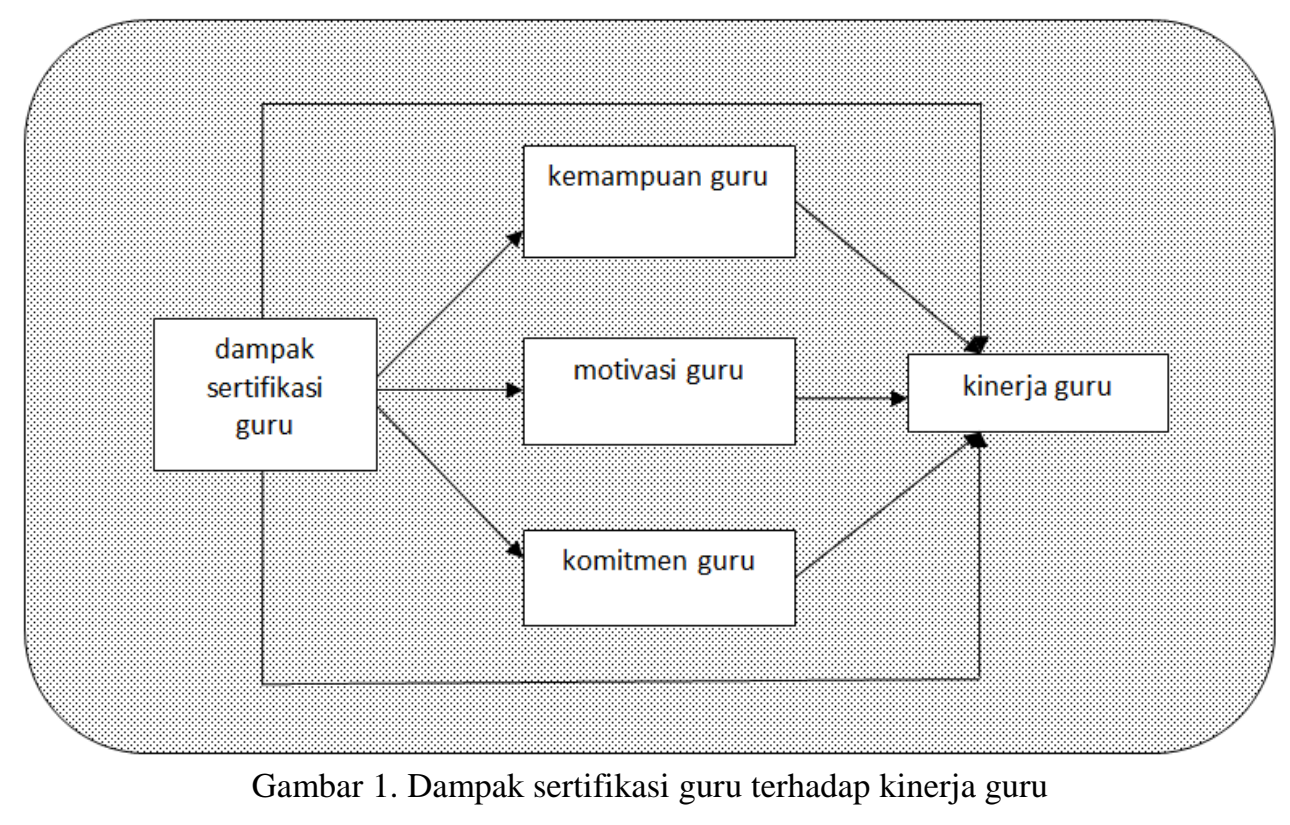

\section{HASIL DAN PEMBAHASAN}

Deskripsi data kuantitatif dalam penelitian ini disajikan dalam bentuk distribusi frekuensi kategorik, ukuran tendensi sentral (mean, modus dan median), variabilitas (standar deviasi dan varians), dan bentuk grafik pareto serta grafik histogram. Variabel penelitian yang dideskripsikan tersebut adalah: (1) variabel Dampak Sertifikasi Guru $\left(\mathrm{X}_{1}\right),(2)$ variabel Kemampuan Kerja Guru $\left(\mathrm{X}_{2}\right)$, (3) variabel Motivasi Kerja Guru $\left(\mathrm{X}_{3}\right)$, (4) variabel Komitmen kerja Guru $\left(\mathrm{X}_{4}\right)$, dan (5) variabel Kinerja Guru $\left(\mathrm{X}_{5}\right)$. Setiap variabel penelitian diuraikan dalam beberapa indikator yang terkait dengan variabel yang tersebut.

Variabel Dampak Sertivikasi Guru ditunjukkan melalui indikator kebanggaan, keprofesionalan, dan kesejahteraan. Variabel
Kemampuan Kerja Guru dijabarkan menjadi indikator kompetensi pedagogis, kompetensi professional, kompetensi kepribadian, dan kompetensi sosial. Variabel Motivasi Kerja Guru diindikasikan melalui indikator kebutuhan berprestasi, mengambil tanggungjawab pribadi, kebutuhan eksistensi dan berkuasa, kebutuhan berafiliasi, kebutuhan aktualisasi dan kemandirian, serta harapan pertumbuhan. Variabel Komitmen Kerja Guru dijtunjukkan dengan indikator komitmen afektif, komitmen kontinuitas dan komitmen normatif. Variabel Kinerja Guru dijabarkan melalui indikator pelaksanaan tugas pokok, pelaksanaan tugas di luar tugas pokok, dan pengembangan profesionalisme, kepribadian dan sosial. Terakhir variabel Kinerja Sekolah yang ditunjukkan melalui indikator kurikulum, proses pembelajaran, kompetensi lulusan, 
penilaian, pendidik dan tenaga kependidikan dan pengelolaan.

Variabel pertama adalah dampak sertifikasi guru. Data kuantitatif variabel Dampak Sertifikasi Guru diperoleh dengan menggunakan kuesioner tertutup dengan jumlah butir sebanyak 17 pernyataan. Setiap butir memiliki skor butir minimal 1 dan maksimal 4, sehingga rentang skor variabel ini antara 17 sampai dengan 68. Dengan demikian variabel ini memiliki rerata normatif 42,5 dan nilai simpangan baku normatif 8,5. Hasil analisis data penelitian (empiris) terhadap variabel ini disajikan dalam Tabel 1 . Berdasarkan Tabel 1 tersebut diperoleh rentang skor 21 sampai dengan 68, ukuran tendensi sentral data secara empiris diperoleh nilai rerata 50,38, modus sebesar 46,0, median sebesar 47,0, dan simpangan baku empiris sebesar 9,12 .

Tabel 1. Hasil analisis deskriptif variabel dampak sertifikasi guru dan indikatornya

\begin{tabular}{lrrrr}
\hline & dampak & kebangaan & $\begin{array}{c}\text { Keprofe- } \\
\text { sionalan }\end{array}$ & $\begin{array}{c}\text { Kesejah- } \\
\text { teraan }\end{array}$ \\
\hline Mean & 50.3800 & 32.5800 & 5.1600 & 12.6400 \\
Median & 47.0000 & 31.5000 & 6.0000 & 12.0000 \\
Mode & 46.00 & 30.00 & 6.00 & 11.00 \\
Std. Deviation & 9.12697 & 5.70030 & 1.55655 & 3.40923 \\
Variance & 83.302 & 32.493 & 2.423 & 11.623 \\
Range & 47.00 & 26.00 & 6.00 & 15.00 \\
Minimum & 21.00 & 14.00 & 2.00 & 5.00 \\
Maximum & 68.00 & 40.00 & 8.00 & 20.00 \\
Sum & 2519.00 & 1629.00 & 258.00 & 632.00 \\
\hline
\end{tabular}

Kecenderungan data variabel dampak sertifikasi guru dapat diketahui dengan membandingkan nilai rerata empiris dengan rerata normatif dan nilai modusnya. Hasil perhitungan rerata empiris variabel ini diperoleh 50,38 dan nilai modus sebesar 46 . Data ini menunjukkan bahwa nila rerata empiris lebih besar dibandingkan dengan nilai rerata normatif $(42,5)$. Data ini menunjukkan bahwa kecenderungan data kuantitatif dampak sertifikasi guru SMK secara keseluruhan termasuk dalam kategori "tinggi”.

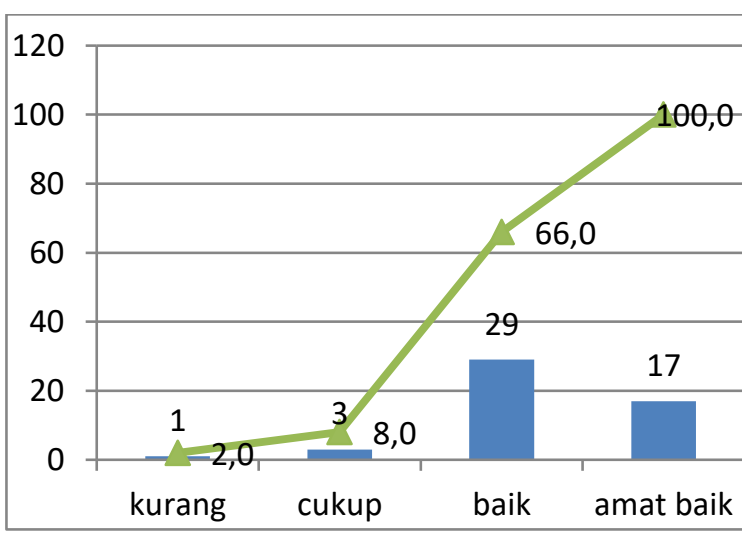

Gambar 2. Grafik pareto kecenderungan data variabel dampak sertifikasi guru

Variabel berikutnya adalah kemampuan kerja guru. Data kuantitatif variabel Kemampuan kerja Guru SMK pasca sertifikasi diperoleh dengan menggunakan kuesioner tertutup dengan jumlah butir sebanyak 67 pernyataan. Setiap butir memiliki skor butir minimal 1 dan maksimal 4, sehingga rentang skor variabel ini antara 67 sampai dengan 268 . Dengan demikian variabel ini memiliki rerata normatif 167,5 dan nilai simpangan baku normatif 33,5. Berdasarkan data pada Tabel 2, hasil analisis data penelitian (empiris) terhadap variabel ini diperoleh rentang skor 112,0 sampai dengan 266,0 ukuran tendensi sentral data secara empiris diperoleh nilai rerata 203,36, modus sebesar 173,0 median sebesar 196,0 dan simpangan baku empiris sebesar 34,25 .

Tabel 2. Hasil analisis deskriptif variabel kemampuan kerja guru dan indikatornya

\begin{tabular}{|c|c|c|c|c|c|}
\hline & $\begin{array}{c}\text { Kemam- } \\
\text { puan }\end{array}$ & pedagogis & $\begin{array}{l}\text { Profe- } \\
\text { sional }\end{array}$ & $\begin{array}{c}\text { Kepriba- } \\
\text { dian }\end{array}$ & sosial \\
\hline Mean & 203.3600 & 106.8600 & 28.9800 & 44.9200 & 22.6000 \\
\hline $\begin{array}{l}\text { Std. Error } \\
\text { of Mean }\end{array}$ & 4.84442 & 2.57080 & .74969 & 1.11129 & .64015 \\
\hline Median & 196.0000 & 105.0000 & 28.5000 & 44.5000 & 22.0000 \\
\hline Mode & 173.00 & 105.00 & 25.00 & 42.00 & 23.00 \\
\hline $\begin{array}{l}\text { Std. } \\
\text { Deviation }\end{array}$ & 34.25520 & 18.17827 & 5.30110 & 7.85803 & 4.52657 \\
\hline Variance & 1173.419 & 330.449 & 28.102 & 61.749 & 20.490 \\
\hline Range & 154.00 & 86.00 & 26.00 & 25.00 & 19.00 \\
\hline Minimum & 112.00 & 52.00 & 14.00 & 31.00 & 13.00 \\
\hline Maximum & 266.00 & 138.00 & 40.00 & 56.00 & 32.00 \\
\hline Sum & 10168.00 & 5343.00 & 1449.00 & 2246.00 & 1130.00 \\
\hline
\end{tabular}


Kecenderungan data variabel kemampuan kerja guru dapat diketahui dengan membandingkan nilai rerata empiris dengan rerata normatif dan nilai modusnya. Hasil perhitungan rerata empiris variabel ini diperoleh 203,36 dan nilai modus sebesar 173,0. Data ini menunjukkan bahwa nila rerata empiris lebih besar dibandingkan dengan nilai rerata normatif $(167,5)$. Data ini menunjukkan bahwa kecenderungan data kuantitatif kemampuan kerja guru SMK pasca sertifikasi termasuk dalam kategori "tinggi".

Kecenderungan data kuantitatif kemampuan kerja guru SMK pasca sertifikasi dapat juga diketahui melalui distribusi frekuensi kategorik. Gambar 3 menunjukkan kecenderungan variabel kemampuan kerja guru SMK sebesar 32\% termasuk dalam kategori "amat baik", $60 \%$ termasuk dalam kategori baik, dan $6 \%$ termasuk dalam kategori "cukup", dan 2\% termasuk kategori "kurang". Dengan demikian, kecenderungan variabel kemampuan kerja guru SMK secara keseluruhan dapat dikatakan sebagian besar termasuk dalam kategori "tinggi".

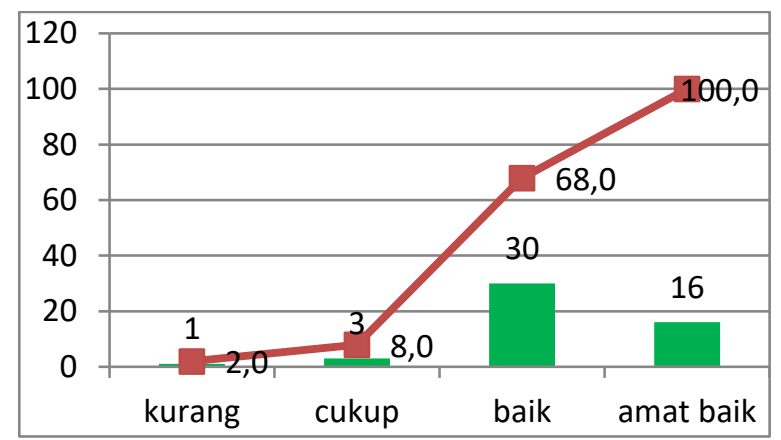

Gambar 3. Grafik Pareto kecenderungan data variabel kemampuan kerja guru

Data kuantitatif variabel motivasi kerja guru SMK pasca sertifikasi diperoleh dengan menggunakan kuesioner tertutup dengan jumlah butir sebanyak 45 pernyataan. Setiap butir memiliki skor butir minimal 1 dan maksimal 4, sehingga rentang skor variabel ini antara 45 sampai dengan 180. Dengan demikian variabel ini memiliki rerata normatif 112,5 dan nilai simpangan baku normatif 22,5.
Tabel 3 Hasil analisis deskriptif variabel motivasi kerja guru dan indikatornya

\begin{tabular}{lrrrrrr}
\hline & $\begin{array}{c}\text { Moti- } \\
\text { vasi }\end{array}$ & $\begin{array}{c}\text { Berpres- } \\
\text { tasi }\end{array}$ & $\begin{array}{c}\text { Eksis- } \\
\text { tensi }\end{array}$ & $\begin{array}{c}\text { Berafi- } \\
\text { liasi }\end{array}$ & $\begin{array}{c}\text { Aktua- } \\
\text { lisasi }\end{array}$ & $\begin{array}{c}\text { Partum- } \\
\text { buhan }\end{array}$ \\
\hline Mean & 130.8200 & 47.3000 & 22.8200 & 22.3000 & 20.7400 & 17.6600 \\
$\begin{array}{l}\text { Std. Error } \\
\text { of Mean }\end{array}$ & 3.08051 & 1. & .62577 & .60962 & .43595 & .44686 \\
Median & 127.0000 & 47.5000 & 22.5000 & 22.0000 & 20.0000 & 17.0000 \\
Mode & 126.00 & 48.00 & 22.00 & 22.00 & 21.00 & 16.00 \\
Std. & 21.78250 & 8.17225 & 4.42484 & 4.31064 & 3.08260 & 3.15976 \\
$\begin{array}{l}\text { Deviation } \\
\text { Variance }\end{array}$ & 474.477 & 66.786 & 19.579 & 18.582 & 9.502 & 9.984 \\
Range & 89.00 & 36.00 & 18.00 & 18.00 & 14.00 & 14.00 \\
Minimum & 84.00 & 28.00 & 13.00 & 12.00 & 13.00 & 10.00 \\
Maximum & 173.00 & 64.00 & 31.00 & 30.00 & 27.00 & 24.00 \\
Sum & 6541.00 & 2365.00 & 1141.00 & 1115.00 & 1037.00 & 883.00 \\
\hline
\end{tabular}

Hasil analisis data penelitian (empiris) terhadap variabel ini diperoleh rentang skor 84 sampai dengan 173, ukuran tendensi sentral data secara empiris diperoleh nilai rerata 130,82, modus sebesar 126 median sebesar 127 dan simpangan baku empiris sebesar 21,78. Kecenderungan data variabel motivasi kerja guru dapat diketahui dengan membandingkan nilai rerata empiris dengan rerata normatif dan nilai modusnya. Hasil perhitungan rerata empiris variabel ini diperoleh 130,82 . dan nilai modus sebesar 126. Data ini menunjukkan bahwa nila rerata empiris lebih besar dibandingkan dengan nilai rerata normatif $(112,5)$. Data ini menunjukkan bahwa kecenderungan data kuantitatif motivasi kerja guru SMK pasca sertifikasi termasuk dalam kategori "tinggi".

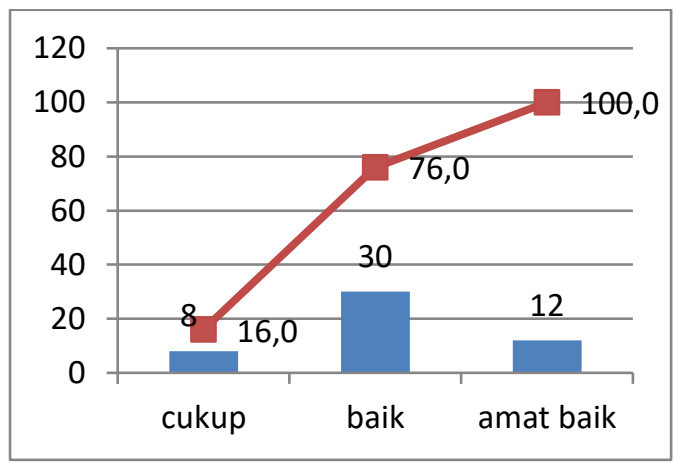

Gambar 4. Grafik Pareto kecenderungan data variabel motivasi kerja guru 
Berdasarkan distribusi frekuensi kategorik ini dapat disajikan dalam bentuk grafik Pareto seperti ditunjukkan pada Gambar 4. Gambar 4 menunjukkan kecen-derungan variabel motivasi kerja guru SMK sebesar $24 \%$ termasuk dalam kategori "amat baik", $60 \%$ termasuk dalam kategori baik, dan $16 \%$ termasuk dalam kategori "cukup". Dengan demikian, kecenderungan variabel motivasi kerja guru SMK pasca sertifikasi secara keseluruhan dapat dikatakan sebagian besar termasuk dalam kategori "tinggi".

Data kuantitatif variabel komitmen kerja guru SMK pasca sertifikasi diperoleh dengan menggunakan kuesioner tertutup dengan jumlah butir sebanyak 27 pernyataan. Setiap butir memiliki skor butir minimal 1 dan maksimal 4, sehingga rentang skor variabel ini antara 27 sampai dengan 108. Dengan demikian variabel ini memiliki rerata normatif 67,5 dan nilai simpangan baku normatif 13,5. Berdasarkan Tabel 5 hasil analisis data penelitian (empiris) terhadap variabel ini diperoleh rentang skor 52 sampai dengan 108, ukuran tendensi sentral data secara empiris diperoleh nilai rerata 81,14 , modus sebesar 77 median sebesar 79 dan simpangan baku empiris sebesar 12,88 .

Tabel 4. Hasil analisis deskriptif variabel komitmen kerja guru dan indikatornya

\begin{tabular}{lrrrr}
\hline & $\begin{array}{c}\text { komitm } \\
\text { en }\end{array}$ & afektif & $\begin{array}{c}\text { kontinui } \\
\text { tas }\end{array}$ & $\begin{array}{c}\text { normati } \\
\text { ve }\end{array}$ \\
\hline Mean & 81.1400 & 34.2800 & 32.3600 & 14.5000 \\
$\begin{array}{l}\text { Std. Error } \\
\text { of Mean }\end{array}$ & 1.82231 & .86757 & .68617 & .39615 \\
Median & 79.0000 & 33.0000 & 32.0000 & 14.0000 \\
Mode & $77.00^{\mathrm{a}}$ & 33.00 & 32.00 & 15.00 \\
Std. & 12.8857 & 6.13468 & 4.85193 & 2.80124 \\
Deviation & 0 & & & \\
Variance & 166.041 & 37.634 & 23.541 & 7.847 \\
Range & 56.00 & 24.00 & 24.00 & 14.00 \\
Minimum & 52.00 & 20.00 & 20.00 & 6.00 \\
Maximum & 108.00 & 44.00 & 44.00 & 20.00 \\
Sum & 4057.00 & 1714.00 & 1618.00 & 725.00 \\
\hline
\end{tabular}

Kecenderungan data variabel komitmen kerja guru dapat diketahui dengan membandingkan nilai rerata empiris dengan rerata normatif dan nilai modusnya. Hasil perhitungan rerata empiris variabel ini diperoleh 81,14 dan nilai modus sebesar 77 . Data ini menunjukkan bahwa nila rerata empiris lebih besar dibandingkan dengan nilai rerata normatif $(67,5)$. Data ini menunjukkan bahwa kecenderungan data kuantitatif komitmen kerja guru SMK pasca sertifikasi termasuk dalam kategori "tinggi”.

Kecenderungan data kuantitatif komitmen kerja guru SMK pasca sertifikasi dapat juga diketahui melalui distribusi frekuensi kategorik. seperti ditunjukkan pada Gambar 5. Gambar 5 menunjukkan kecenderungan variabel komitmen kerja guru SMK sebesar $26 \%$ termasuk dalam kategori "amat baik", 64\% termasuk dalam kategori baik, dan $10 \%$ termasuk dalam kategori "cukup". Dengan demikian, kecenderungan variabel komitmen kerja guru SMK pasca sertifikasi secara keseluruhan dapat dikatakan sebagian besar termasuk dalam kategori "tinggi".

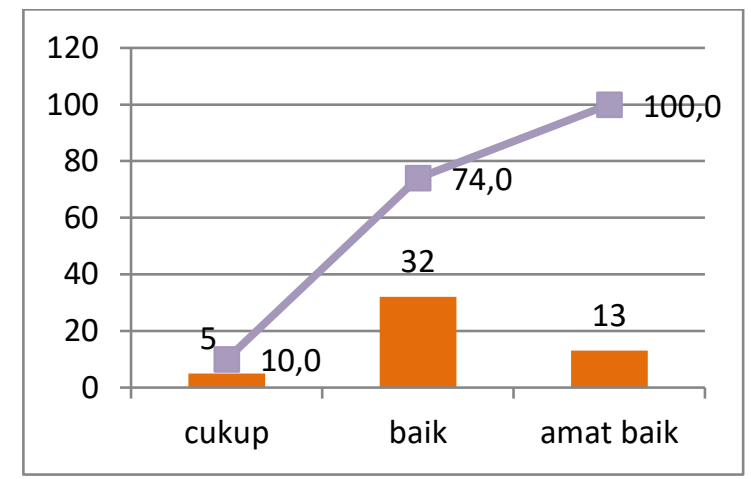

Gambar 5. Grafik Pareto kecenderungan data variabel komitmen kerja guru

Data kuantitatif variabel kinerja guru SMK pasca sertifikasi diperoleh dengan menggunakan kuesioner tertutup dengan jumlah butir sebanyak 45 pernyataan. Setiap butir memiliki skor butir minimal 1 dan maksimal 4, sehingga rentang skor variabel ini antara 45 sampai dengan 180. Dengan demikian variabel ini memiliki rerata normatif 112,5 dan nilai simpangan baku normatif 22,5. 
Hasil analisis data penelitian (empiris) terhadap variabel ini diperoleh rentang skor 81 sampai dengan 172, ukuran tendensi sentral data secara empiris diperoleh nilai rerata 129,16, modus sebesar 114,0 median sebesar 124,5 dan simpangan baku empiris sebesar 19,99 .

Kecenderungan data variabel kinerja guru dapat diketahui dengan membandingkan nilai rerata empiris dengan rerata normatif dan nilai modusnya. Hasil perhitungan rerata empiris variabel ini diperoleh 129,16 dan nilai modus sebesar 114. Data ini menunjukkan bahwa nila rerata empiris lebih besar dibandingkan dengan nilai rerata normatif $(112,5)$. Data ini menunjukkan bahwa kecenderungan data kuantitatif kinerja guru SMK pasca sertifikasi termasuk dalam kategori "tinggi".

Tabel 5. Hasil analisis deskriptif variabel kinerja guru dan indikatornya

\begin{tabular}{lrrrr} 
& \multicolumn{1}{c}{$\begin{array}{c}\text { Kinerja } \\
\text { guru }\end{array}$} & \multicolumn{1}{c}{$\begin{array}{c}\text { tugas } \\
\text { pokok }\end{array}$} & $\begin{array}{c}\text { non tugas } \\
\text { pokok }\end{array}$ & $\begin{array}{r}\text { Pengem- } \\
\text { bangan }\end{array}$ \\
\hline Mean & 129.1600 & 90.1400 & 26.3400 & 12.6800 \\
$\begin{array}{l}\text { Std. Error of } \\
\text { Mean }\end{array}$ & 2.82718 & 1.68862 & .92388 & .53333 \\
Median & 124.5000 & 87.0000 & 27.0000 & 12.0000 \\
Mode & $114.00^{\mathrm{a}}$ & $82.00^{\mathrm{a}}$ & 28.00 & 9.00 \\
Std. & 19.99118 & 11.94034 & 6.53284 & 3.77121 \\
Deviation & 399.647 & 142.572 & 42.678 & 14.222 \\
Variance & 91.00 & 51.00 & 28.00 & 12.00 \\
Range & 81.00 & 61.00 & 13.00 & 7.00 \\
Minimum & 172.00 & 112.00 & 41.00 & 19.00 \\
Maximum & 6458.00 & 4507.00 & 1317.00 & 634.00 \\
Sum & & & & \\
\hline
\end{tabular}

Kecenderungan data kuantitatif kinerja guru SMK pasca sertifikasi dapat juga diketahui melalui distribusi frekuensi kategorik. Gambar 6 menunjukkan kecenderungan variabel kinerja guru SMK sebesar $20 \%$ termasuk dalam kategori "amat baik", 64\% termasuk dalam kategori baik, dan $16 \%$ termasuk dalam kategori "cukup". Dengan demikian, kecenderungan variabel kinerja guru SMK pasca sertifikasi secara keseluruhan dapat dikatakan sebagian besar termasuk dalam kategori "tinggi".

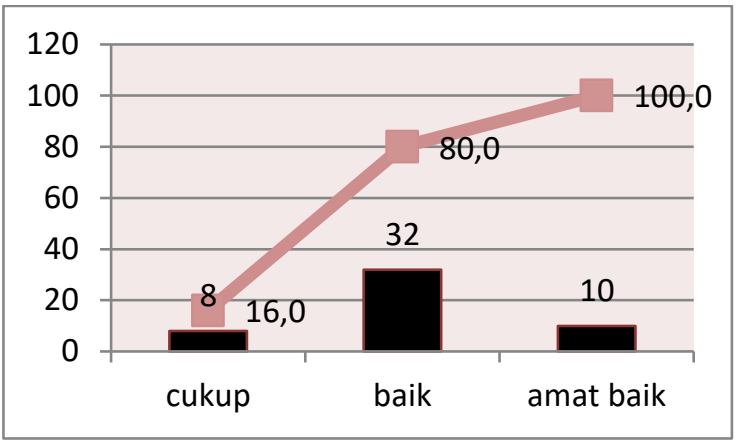

Gambar 6. Grafik Pareto kecenderungan data variabel kinerja guru

Hasil analisis deskriptif pada variabel dampak sertifikasi guru SMK diperoleh informasi bahwa sekitar 34\% dari aspek-aspek kebanggaan, keprofesionalan dan kesejahteraan termasuk dalam kategori amat baik, 58\% masuk kategori baik, 6\% masuk kategori cukup dan $2 \%$ masuk kategori kurang. Hal ini menunjukkan sebagian besar guru SMK di DIY telah mengalami perubahan sikap dalam bekerja sebagai akibat dari diperolehnya sertifikat pendidik professional. Sebagian besar guru produktif SMK bersertifikat pendidik telah mengalami perubahan rasa bangga atas profesi yang disandangnya. Hal ini didukung oleh fakta bahwa sekitar $88 \%$ guru produktif SMK menyatakan dirinya lebih bangga berprofesi sebagai guru setelah diperolehnya sertifikat pendidik professional.

SMK sebagai bagian dari sistem pendidikan nasional merupakan suatu lembaga profesional. Sekolah bertujuan membentuk anak didik menjadi manusia dewasa yang berkepribadian matang dan tangguh, yang dapat dipertanggungjawabkan, bertanggung jawab terhadap masyarakat dan terhadap dirinya. Para lulusan SMK pada waktunya harus mampu bekerja mengisi lapangan kerja yang ada. Peserta didik harus dipersiapkan melalui program pendidikan di sekolah. Adalah keniscayaan bahwa tanggung jawab pendidikan peserta didik terletak di tangan para guru. Oleh sebab itu guru harus diakui sebagai profesi yang sama dengan profesi yang lainnya. Menumbuhkan kebanggaan dalam 
bekerja dikalangan guru mendorong militansi guru untuk total dalam berkarya, bersemangat dalam melaksanakan tugas dan fungsinya secara efisien dan efektif. Hal ini hanya mungkin dilakukan jika kedudukan, fungsi, dan peran guru diakui sebagai suatu profesi yang terhormat.

Berdasarkan analisis data dampak sertifikasi guru yang digali dari aspek keprofesionalan, yakni pemanfaatan pengembangan profesi pendidik untuk meningkatkan kompetensi dan karier pendidik, sebagaian besar (52\%) pendidik telah terpacu untuk melakukan peningkatan komptensi dan kariernya, dan sisanya (48\%) masih memerlukan pembinaan dan pemberdayaan secara terus-menerus agar berubah menjadi lebih professional.

Hasil analisis deskriptif terhadap variabel dampak sertifikasi guru SMK dari aspek kesejahteraan menghasilkan informasi bahwa sebagian kecil (46\%) guru produktif SMK merasa telah mengalami perbaikan kesejahteraan semenjak memperoleh sertifikat pendidik professional, sedangkan sisanya (54\%) berpendapat bahwa guru produktif SMK merasa belum sejahtera. Hal ini menunjukkan masih terjadi kesenjangan antara harapan dengan kenyataan. Tidak dapat dipungkiri bahwa tunjangan sertifikasi diharapkan mampu mendorong guru-guru produktif SMK untuk meningkatkan kompetensi melalui pemanfaatan IT, penambahan sumber bahan ajar (referensi) yang terkini, penelitian atau pendidikan dan pelatihan. Fakta tersebut menunjukkan masih dibutuhkannya upaya yang serius untuk membina dan memberdayakan guru produktif SMK.

Hasil analisis deskriptif terhadap kemampuan guru produktif SMK memberikan informasi bahwa sebagian besar guru (92\%) telah memiliki kemampuan yang tinggi pada aspek kompetensi pedagogis, professional, kepribadian dan sosial. Seorang guru harus mempunyai kemampuan dalam menguasai materi pembelajaran secara luas. Penguasaan ini meliputi konsep dan struktur, serta metoda keilmuan atau teknologi atau seni yang sesuai dengan materi ajar. Guru profesional mengenal karakteristik dari peserta didik, meluangkan waktu untuk memberi perhatian pada siswa di setiap pelajaran atau diskusi yang dilakukan serta memiliki kepekaan mendengar keluhan siswanya.

Pada penelitian ini diperoleh informasi terkait kompetensi pedagogis guru produktif SMK bahwa sebagian besar guru produktif SMK (90\%) termasuk dalam kategori baik. Hal ini menunjukkan bahwa sebagian besar guru SMK telah memiliki kemampuan mengelola pembelajaran peserta didik yang meliputi pemahaman terhadap peserta didik, perancangan dan pelaksanaan pembelajaran, evaluasi hasil belajar, dan pengembangan peserta didik untuk mengaktualisasikan berbagai potensi yang dimilikinya.

Dari aspek kompetensi professional diperoleh informasi bahwa sebagian besar guru (68\%) termasuk dalam ketegori baik dan sekitar 32\% termasuk kategori kurang. Hal ini menunjukkan masih perlunya pembinaan dan pemberdayaan guru produktif SMK yang terkait dengan peningkatan kompetensi professional. Melalui pembinaan dalam hal penguasaan materi, struktur, konsep dan pola pikir keilmuan yang mendukung mata pelajaran yang diampu, seorang guru SMK akan berdaya dalam memilih dan menentukan materi yang relevan dengan kebutuhan dan kemampuan peserta didik.

Berdasarkan aspek kompetensi kepribadian diperoleh informasi bahwa sebagian besar $(86 \%)$ guru produktif SMK termasuk dalam kategori baik, sedangkan sebagian kecil (14\%) termasuk dalam kategori kurang. Hal ini menunjukkan bahwa pelaksanaan tugas sebagai guru telah didukung oleh suatu perasaan bangga akan tugas yang dipercayakan kepadanya untuk mempersiapkan generasi berkualitas di masa depan. Pendidikan adalah proses yang direncanakan agar semua berkembang melalui proses pembelajaran. Guru sebagai pendidik harus dapat mempengaruhi ke arah proses itu sesuai 
dengan tata nilai yang dianggap baik dan berlaku dalam masyarakat.

Kepribadian guru yang tercermin dari norma, moral, estetika, dan ilmu pengetahuan, akan mempengaruhi perilaku etik siswa sebagai pribadi dan sebagai anggota masyarakat. Penerapan disiplin yang baik dalam proses pendidikan akan menghasilkan sikap mental, watak dan kepribadian siswa yang kuat. Guru dituntut harus mampu membelajarkan siswanya tentang disiplin diri, belajar membaca, mencintai buku, menghargai waktu, belajar bagaimana cara belajar, mema-tuhi aturan/tata tertib, dan belajar bagaimana harus berbuat. Semuanya itu akan berhasil apabila guru juga disiplin dalam melaksanakan tugas dan kewajibannya.

Hasil analisis deskriptif terhadap variabel motivasi kerja guru pasca sertifikasi memberikan informasi bahwa sebagian besar (84\%) termasuk dalam kategori baik, dan sisanya (16\%) termasuk kategori kurang. Secara keseluruhan motivasi kerja guru produktif SMK pasca sertifikasi telah memiliki motivasi yang tinggi dalam melaksanakan tugas. Berarti kebutuhan berprestasi, kebutuhan eksistensi dan berkuasa, kebutuhan berafiliasi, kebutuhan aktualisasi dan kemandirian, serta harapan pertumbuhan sebagian besar guru telah terpenuhi.

Dari aspek kebutuhan berprestasi, sebagian besar (80\%) guru termasuk dalam kategori baik. Hal ini menunjukkan sebagian besar guru produktif SMK memperoleh kesempatan yang adil dari sekolah untuk meraih prestasi kerja optimal dan pengembangan profesionalismenya. Selanjutnya dari aspek kebutuhan eksistensi dan berkuasa sebagian besar $(76 \%)$ termasuk dalam kategori baik. Guru memiliki kesempatan yang sama untuk menyelesaikan tugas-tugas yang terkait dengan pembelajaran dan menentukan solusinya, memiliki kebebasan yang bertanggung jawab dalam membimbing peserta didik, dan keberhasilan dalam memperoleh penghargaan atas pekerjaan yang diselesaikan.
Hasil analisis deskriptif terhadap variabel komitmen kerja guru produktif SMK diperoleh informasi bahwa sebagian besar (90\%) termasuik dalam kategori baik. Hal ini memberikan informasi bahwa guru-guru produktif SMK sebagian besar memiliki ikatan emosional yang tak terpisahkan dari sekolah, memiliki kesiapan yang tinggi dalam mendukung program-program sekolah serta guru memperoleh manfaat kemuliaan, kenyamanan, kebahagiaan dan kesejahteraan dari tugas-tugas yang dilakukan di sekolah.

Hasil analisis deskriptif terhadap variabel kinerja guru memberikan informasi bahwa sebagian besar (84\%) termasuk dalam kategori baik. Hal ini menunjukkan bahwa guru produktif SMK dalam melaksanakan tugas pokok, pelaksanaan tugas diluar tugas pokok dan pengembangan profesionalisme telah mengalami perubahan yang relatif positif.

\section{SIMPULAN}

Dampak sertifikasi guru SMK yang dikembangkan dari aspek kebanggaan, keprofesionalan dan kesejahteraan secara keseluruhan diperoleh informasi sebesar 34\% termasuk kategori amat baik, 58\% termasuk kategori baik, 6\% kategori cukup dan 2\% termasuk kategori kurang. Kemampuan kerja guru yang dikembangkan dari aspek kompetensi pedagogis, professional, kepribadian dan sosial secara keseluruhan diperoleh informasi sebesar $32 \%$ termasuk kategori amat baik, 60\% kategori baik, 6\% cukup dan 2\% termasuk kategori kurang. Motivasi kerja guru yang diindikasikan dari aspek kebutuhan berprestasi, eksistensi dan berkuasa, berafiliasi, aktualisasi dan kemandirian, dan harapan pertumbuhan diperoleh informasi sebesar $24 \%$ termasuk kategori amat baik, 60\% termasuk kategori baik, dan $16 \%$ masuk kategori cukup. Komitmen kerja guru yang dikembangkan dari aspek komitmen afektif, kontinuitas dan normative diperoleh temuan sebesar $26 \%$ termasuk aktegori amat baik, $64 \%$ termasuk 
kategori baik, dan 10\% masuk kategori cukup. Kinerja guru SMK yang dikembangkan dari aspek pelaksanaan tugas pokok, pelaksanaan tugas di luar tugas pokok dan pengembangan keprofesionalan diperoleh informasi sebesar $20 \%$ termasuk kategori amat baik, 64\% termasuk aktegori baik, dan $16 \%$ termasuk kategori cukup.

\section{DAFTAR RUJUKAN}

Arends, R.I. 2004. Learning to teach $6^{\text {th }}$ edition. New York: McGraw Hill.

Cresswel. 2009. Research design: qualitative, quantitative, and mix methods approaches. Los Angeles: Sage Publications.

Depdiknas. 2008. Teropong wajah sekolah menengah kejuruan di Indonesia. Jakarta: Direktorat Jenderal Manajemen Pendidikan Dasar dan Menengah, Departemen Pendidikan Nasional.

Depdiknas. 2008a. Pedoman Sertfikasi Guru dalam Jabatan. Jakarta: Direktorat Jenderal Pendidikan Tinggi, Departemen Pendidikan Nasional.

Fullan, M. 2001. The new meaning of educational change. Toronto: Irwin Publishing.

Governing Board Member of TVET. 2004. Issues and trends for TVET in South East Asia. Diambil pada tanggal 30
Mei 2008 dari http://mail.voctech.org.bn:987/onlinere g/PaperPresenter/o1Manajement/04Sai ful.pdf.

Jones, J., Jenkin, M., \& Loed, S. 2006. Developing effective teacher performance. London: Paul Chapman Publishing.

Joy Nam, Y. J. 2009. Pre-Employment Skills Development Strategies in the OECD. Discussion Paper No. 0923. Social protection and labor the World Bank. November 2009. p.3

Kompas, (Januari 2009). Satu dari Enam Lulusan SMK Jadi Pengangguran. (5 Januari 2009). http://kesehatan.kompas.com/read/2009/01/ 05/16322142/Satu.dari.Enam. Lulusan.SMK.Jadi.Pengangguran

Tilaar, H. A. R. 2000. Paradigma baru pendidikan nasional. Jakarta: PT. Rineka Cipta.

Trilling, B. \& Hood, P. 1999. Learning, Technology, and Education Reform in the Knowledge Age or "We're Wired, Webbed, and Windowed, Now What"? Educational Technology May-June 1999. p. 5-18.

UNDP. 2008. Human Development Report Indonesia. Diambil pada tanggal 28 Juli 2009 dari http://hdrstats.undp.org/countries/count ry_fact_sheets/cty_fs_IDN. html.

Wen, S. (2003). Future of education. Batam: Lucky Publishers. 